REFLECTIONS:

NEUROLOGY AND

THE HUMANITIES

Section Editor

Anne W. McCammon,

MD, FAAN

\title{
Please don't send me home
}

\section{Demyelinating disease, desert heat, and dedication}

Jack E. Riggs, MD, CAPT, MC, USN (Ret)

Correspondence to Dr. Riggs: jriggs@wvu.edu
"Doctor, please don't send me home!" the major begged.

The tone of his plea told me that he already knew what my response had to be. This army major was a reservist, like me. He had been in the Army National Guard for 15 years. This was his first forward deployment to a combat zone.

"Doctor ... please ... if you send me home, I will never have an opportunity to serve my country like this again." The tears in the major's eyes were breaking my heart.

"Major, you have nothing to prove to anybody, including yourself. You are already here. You have already honorably served your country in a forward capacity. I am humbled and stand in awe of your dedication, patriotism, and perseverance. But I cannot allow you to remain here."

One hot summer evening, the doctor in casualty receiving called me to come see this major from headquarters with difficulty walking. The 36-year-old major sitting on a gurney appeared to be very fit and trim. Since he was there for gait problems, I asked him to hop off the gurney and take a few steps.

Well, he could not hop off the gurney. He could barely move from the gurney and nearly toppled to the floor. When he attempted to take a few steps, it was obvious that he had a severe spastic gait. He could barely stand unassisted.

"Major, how long have you had this problem?" I asked.

"About 6 weeks, Colonel," he responded. I had long ago given up explaining to soldiers that I was a navy captain, not an army colonel.

"How long have you been in country?"

"Two weeks, Sir."

This was amazing.

"Are you telling me that you were deployed here and you could barely walk?" This story was almost unbelievable.

"Well my problems have gotten worse since I've been here."

I soon learned this soldier had been in civilian life, among other things, a NCAA Division 1 basketball referee. Six months previously, he had been effortlessly running up and down a basketball court, easily keeping up with talented and gifted athletes barely over half his age.

I questioned him about his mobilization process and how he got past medical screening procedures back in the States before being deployed. He had been an individual augment, which meant he had been processed at a CRC (Combat Readiness Center). Indeed, he had not been able to keep up with his original mobilization group and had completed the process with a subsequent group. He had performed so well on his previous army physical fitness tests that he was able to convince medical examiners at the CRC that his gait difficulties were the result of straining muscles in his legs and back. He had even been treated with a short course of oral steroids at the CRC to decrease "inflammation of the spine." Believing his impairment was transient and reflecting some recent unspecified and indeterminate injury, medical personnel gave him a pass. He was, after all, a military officer, outranking them and assuring them that he was "good to go." I asked the major if anyone at the CRC had tested his reflexes or stroked the bottom of his feet. They had not. The major had prominent bilateral Babinski signs and sustained clonus at both ankles. Pathologic spread of his reflexes at other locations was present, including a brisk jaw jerk.

I asked the major why he had decided to come to the hospital this particular evening seeking medical attention. His response was simple, blunt, and easily understood. He had been ordered to. His lieutenant colonel superior had become tired of watching the major's struggling gait and had ordered him to report to the hospital. The major worked "behind the wire" in a very information-secure and restricted area of Camp Arifjan. In order to keep a low profile, the major would arrive at work well before others and leave when only a skeleton duty section was present. He was unable to walk to the DFAC (dining facilities) for meals. He had junior enlisted personnel bring him his meals as he was "too busy" to take meal breaks. Of course they complied. As he had difficulties with his bowel and bladder function, he would force himself 
Figure Photograph of the author next to a thermometer in Kuwait during the summer of 2005

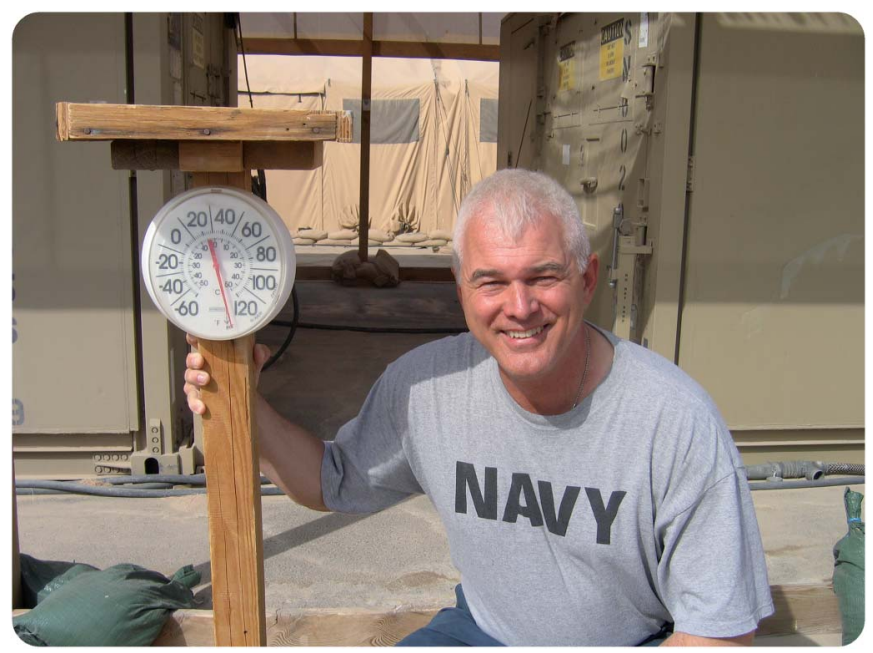

These extremely hot ambient temperatures produced focal neurologic symptoms and signs in service members with previously unrecognized demyelinating disease.

to move his bowels before his early arrival and after his late departure from work. Because he could not make it in time to the latrine (army jargon for toilet, or head using navy jargon) during the day, he kept a jug underneath his desk to collect his urine. That the major had managed to keep up this routine for 2 weeks was a testament to his dedication.

I next began questioning the major about prior episodes of neurologic dysfunction. Sure enough, 2 years previously he had been diagnosed with optic neuritis. He said he had fully recovered and had been treated at that time with a short course of oral steroids. I asked the major if anyone had mentioned the words multiple sclerosis to him. They had. $\mathrm{He}$ had been told that his optic neuritis could be the first sign of multiple sclerosis, but he added the doctor had told him that he did not have any other evidence of multiple sclerosis on his brain MRI. I asked him if he had told his National Guard unit about this episode of optic neuritis. He had not.

I informed the major that he was going to be admitted to the hospital and treated with high-dose IV steroids. The next scheduled medevac flight out of Kuwait to Germany was in 72 hours. I told the major he would be on that flight and would be through-regulated back to Walter Reed Army Medical Center in Washington, DC.

The major had been self-limiting his fluid and food intake for 2 weeks. He was understandably thirsty and hungry. The hospital obtained patient food from one of the camp DFACs. Since it was past the dinner meal time, I sent for 2 duty corpsmen. I explained to the corpsmen that the major was very unstable walking and that he did not have good control of his bowels or bladder. They were to obtain a duty vehicle and transport the major to one of the DFACs for midrats (midnight rations). Under no circumstance were they to allow the major to fall, to carry his own tray, or to embarrass himself. They were to discretely bring a urinal with them. They were to identify the major as an inpatient of US Military Hospital Kuwait to the DFAC official at the door and themselves as hospital corpsmen assigned to assist the major with obtaining his meal. I gave the corpsmen my cell phone number and instructed them that if anyone had issues they were to call $\mathrm{me}$, the hospital commanding officer, for clarification.

The following day, MRIs of the major's brain, cervical cord, and thoracic cord were obtained in $\mathrm{Ku}-$ wait City. Those MRIs showed several enhancing and nonenhancing white matter lesions. The major did note some improvement in his symptoms with the high-dose IV steroids that he received before his departure from Kuwait.

Kuwait is one of the hottest locations on the globe. Daytime highs regularly topped 125 degrees Fahrenheit in the summer at Camp Arifjan (figure). Well over 100,000 troops annually transited Kuwait at the height of the war in Iraq. As a neurologist, I had learned that previously asymptomatic demyelinating CNS lesions may become symptomatic when increases in body temperature occurred. On a handful of occasions in Kuwait, I observed this phenomenon firsthand. Neurologically normal troops, at least by self-reported history, arrived in Kuwait and within a couple of days developed focal neurologic symptoms and signs. Brain MRIs in those troops revealed nonenhancing white matter lesions that by appearance and location were suggestive of multiple sclerosis, albeit currently inactive disease.

The United States currently has an all-volunteer military. Thus, if you are a member of the US armed forces, you chose to be a member. At the time that I was in Kuwait, nearly half of the troops in that theater of operations were members of the National Guard or Reserves. Consequently, these troops had received the vast majority of their medical care from civilian providers. If you want to serve in the military, it may not be in your best interest to bring to the attention of military officials that you might have a disqualifying medical condition such as multiple sclerosis.

Medicine provides physicians an opportunity for a unique perspective on the human experience. I never fail to be humbled by the dedication and perseverance that some display when challenged with severe physical disability in their efforts to achieve or retain goals and dreams. I never cease to be amazed by situational aberrations and seeming absurdities that emerge in rankdefined societies, such as the military, wherein rank and assertion alone can attempt to mitigate or nullify, at least temporarily, severe physical disability. My experience with this major provided memorable examples of both of these uniquely human phenomena. 


\title{
Neurology
}

\author{
Please don't send me home: Demyelinating disease, desert heat, and dedication \\ Jack E. Riggs \\ Neurology 2016;86;196-197 \\ DOI 10.1212/WNL.0000000000002265
}

\section{This information is current as of January 11, 2016}

\section{Updated Information \& Services \\ Subspecialty Collections}

\section{Permissions \& Licensing}

Reprints including high resolution figures, can be found at: http://n.neurology.org/content/86/2/196.full

This article, along with others on similar topics, appears in the following collection(s):

All Demyelinating disease (CNS)

http://n.neurology.org/cgi/collection/all_demyelinating_disease_cns All Education http://n.neurology.org/cgi/collection/all_education All Ethics in Neurology/Legal issues http://n.neurology.org/cgi/collection/all_ethics_in_neurology_legal_iss ues

Multiple sclerosis

http://n.neurology.org/cgi/collection/multiple_sclerosis

Information about reproducing this article in parts (figures,tables) or in its entirety can be found online at:

http://www.neurology.org/about/about_the_journal\#permissions

Information about ordering reprints can be found online: http://n.neurology.org/subscribers/advertise

Neurology ${ }^{\circledR}$ is the official journal of the American Academy of Neurology. Published continuously since 1951, it is now a weekly with 48 issues per year. Copyright () 2016 American Academy of Neurology. All rights reserved. Print ISSN: 0028-3878. Online ISSN: 1526-632X.

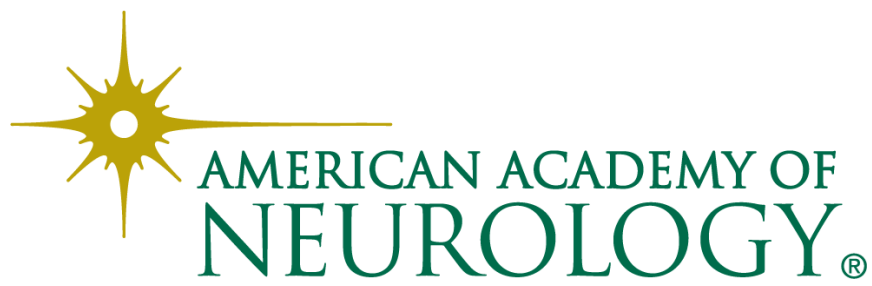

